\title{
Serotonin augmentation therapy by escitalopram has minimal effects on amyloid- $\beta$ levels in early-stage Alzheimer's-like disease in mice
}

Christian Ulrich von Linstow ${ }^{1}$, Jonas Waider ${ }^{2}$, Manuela Grebing ${ }^{1}$, Athanasios Metaxas ${ }^{1}$, Klaus Peter Lesch ${ }^{2,3}$ and Bente Finsen ${ }^{1 *}$ (i)

\begin{abstract}
Background: Dysfunction of the serotonergic (5-HTergic) system has been implicated in the cognitive and behavioural symptoms of Alzheimer's disease (AD). Accumulation of toxic amyloid- $\beta$ (A $\beta$ ) species is a hallmark of $A D$ and an instigator of pathology. Serotonin (5-HT) augmentation therapy by treatment with selective serotonin reuptake inhibitors (SSRIs) in patients with AD has had mixed success in improving cognitive function, whereas SSRI administration to mice with AD-like disease has been shown to reduce A $\beta$ pathology. The objective of this study was to investigate whether an increase in extracellular levels of $5-\mathrm{HT}$ induced by chronic SSRI treatment reduces A $\beta$ pathology and whether 5 -HTergic deafferentation of the cerebral cortex could worsen A $\beta$ pathology in the $\mathrm{APP}_{\text {swe }} / \mathrm{PS}_{\triangle \mathrm{E}}$ (APP/PS1) mouse model of AD.

Methods: We administered a therapeutic dose of the SSRI escitalopram ( $5 \mathrm{mg} / \mathrm{kg} /$ day) in the drinking water of 3-month-old APP/PS1 mice to increase levels of 5-HT, and we performed intracerebroventricular injections of the neurotoxin 5,7-dihydroxytryptamine (DHT) to remove 5-HTergic afferents. We validated the effectiveness of these interventions by serotonin transporter autoradiography (neocortex $79.7 \pm 7.6 \%$ ) and by high-performance liquid chromatography for 5-HT (neocortex 64\% reduction). After 6 months of escitalopram treatment or housing after DHT-induced lesion, we evaluated brain tissue by mesoscale multiplex analysis and sections by IHC analysis.
\end{abstract}

Results: Amyloid- $\beta$-containing plaques had formed in the neocortex and hippocampus of 9-month-old APP/PS1 mice after 6 months of escitalopram treatment and 5-HTergic deafferentation. Unexpectedly, levels of insoluble Aß42 were unaffected in the neocortex and hippocampus after both types of interventions. Levels of insoluble A 40 increased in the neocortex of SSRI-treated mice compared with those treated with vehicle control, but they were unaffected in the hippocampus. 5-HTergic deafferentation was without effect on the levels of insoluble/soluble $A \beta 42$ and $A \beta 40$ in both the neocortex and hippocampus. However, levels of soluble amyloid precursor protein a were reduced in the neocortex after 5-HTergic deafferentation.

Conclusions: Because this study shows that modulation of the 5-HTergic system has either no effect or increases levels of insoluble/soluble A 42 and A 40 in the cerebral cortex of APP/PS1 mice, our observations do not support $5-\mathrm{HT}$ augmentation therapy as a preventive strategy for reducing $A \beta$ pathology.

Keywords: Alzheimer's disease, APP/PS1, Cerebral amyloidosis, 5-HT, SSRI, 5,7-Dihydroxytryptamine, Cerebrospinal fluid (CSF), Biomarker

\footnotetext{
* Correspondence: bfinsen@health.sdu.dk

${ }^{1}$ Department of Neurobiology, Institute of Molecular Medicine, University of

Southern Denmark, J.B. Winsløws Vej 25, 5000 Odense C, Denmark

Full list of author information is available at the end of the article
} 


\section{Background}

Alzheimer's disease (AD) is a devastating neurodegenerative disorder characterised by amyloid and tau pathology, as well as a progressive decay of brain circuitry, leading to cognitive impairment especially affecting memory [1]. In addition to the cholinergic degenerative damage in $\mathrm{AD}$ [2], deterioration of the serotonergic (5-HTergic) system has also attracted attention for its involvement in $\mathrm{AD}$ presentation because the 5HTergic system is involved in the regulation of mood [3] and in memory function [4]. Changes of the 5-HTergic system in AD include loss of raphe neurons $[5,6]$, reduced activity of tryptophan hydroxylase [7] and a reduction in cortical levels of serotonin $(5-\mathrm{HT})[8,9]$. It has been suggested that $\mathrm{AD}$ pathology may even originate in the brainstem, which contains the 5-HTergic neurons clustered in the raphe nuclei $[10,11]$.

The effect of 5-HT augmentation therapy on cognitive function in patients with $\mathrm{AD}$ has been examined in placebo-controlled studies with use of selective serotonin reuptake inhibitors (SSRIs) [12-15], but these studies have had limited success [16]. Retrospective cohort studies, however, reported that SSRI treatment reduces cognitive decline and rate of dementia, although not to the level of the general population $[17,18]$. Conversely, reducing levels of 5 -HT by acute tryptophan depletion worsens cognitive function in patients with $\mathrm{AD}$ [19].

As observed in patients with $\mathrm{AD}$ [20], ageing $\mathrm{APP}_{\mathrm{SWE}} / \mathrm{PS}_{\triangle \mathrm{E} 9}(\mathrm{APP} / \mathrm{PS} 1)$-transgenic mice [21] progressively accumulate amyloid- $\beta(A \beta)$ in their cortex [22] and have reduced density of 5-HTergic fibres and reduced levels of 5-HT [23]. Peroral treatment with 8 $\mathrm{mg} / \mathrm{kg} /$ day citalopram during a period of 4 months has been reported to reduce $A \beta$ pathology in the neocortex and hippocampus of 7-month-old APP/PS1 mice [24]. Intraperitoneal injection of $5 \mathrm{mg} / \mathrm{kg} /$ day paroxetine for 5 months has been shown to retard accumulation of A $\beta 40$ and tau pathology in the hippocampus of 10month-old triple-transgenic $(3 \times \mathrm{Tg})$ mice [25]. A study of amyloid pathology in the hippocampal CA1 region in $3 \times \mathrm{Tg}$ mice fed a high-tryptophan diet for 1 month showed reduction of pathology, which was inversely related to the density of 5-HTergic fibres [26]. Conversely, the opposite strategy of inflicting neurotoxin-induced 5HTergic deafferentation of the forebrain was shown to reduce levels of tau phosphorylation in the neocortex, but not amyloid pathology, in APP/PS1 mice [27].

Given the mixed results of clinical studies and the limited availability of in vivo studies addressing the effect of 5 -HT on $A \beta$ pathology in preclinical models of familial $\mathrm{AD}$, we designed this study to investigate the long-term effect of 5-HT augmentation therapy on cerebrospinal fluid (CSF) and brain levels of A $\beta$ in APP/PS1 mice. To this end, one of the most widely used and most serotonin-selective SSRIs, escitalopram, was administered to 3-month-old APP/PS1 mice for a period of 6 months at a therapeutically relevant dosage of $5 \mathrm{mg} / \mathrm{kg} /$ day. In addition, neurotoxin-induced degeneration of the 5HTergic system was used to study the effect of chronic 5HT reduction on brain levels of $A \beta$ in the APP/PS1 mouse.

After 6 months of treatment with escitalopram, levels of A 340 increased in the neocortex of APP/PS1 mice, whereas CSF levels of $A \beta$ were unaffected. 5-HT deafferentation had no effect on any $A \beta$ species, but it did affect levels of soluble amyloid precursor protein $\alpha$ (sAPP $\alpha$ ). These results demonstrate that chronic modulation of the 5-HTergic system in prodromal and early AD-like pathology in mice may be inefficient and even contraindicated.

\section{Methods \\ Animals}

APP/PS1-Tg mice [21] on a C57BL/6 background were bred and housed in the animal facility at the University of Southern Denmark until they reached 9 months of age. At the age of 3 months, APP/PS1 mice were allocated into groups that were either treated with escitalopram (Cipralex ${ }^{\circ}$; Lundbeck A/S, Copenhagen, Denmark) for 6 months or surgically lesioned with 5,7-dihydroxytryptamine (DHT) and housed for 6 months. Additionally, 9-month-old wild-type littermate mice were included along with 6-month-old APP/PS1 mice to evaluate the specificity/sensitivity of the $A \beta$ mesoscale analysis. Mice were kept in a humidity-controlled (45-65\%) and temperature-controlled $\left(21 \pm 1{ }^{\circ} \mathrm{C}\right)$ environment under a 12:12-h light-dark cycle (lights on at 7 a.m.) with food and water available ad libitum. All experiments were carried out in agreement with the Danish Animal Experiments Inspectorate, Ministry of Environment and Food (2011/562-67 and 2011/ 561-1950).

\section{Treatment with escitalopram}

Groups of 3-month-old APP/PS1 mice received $5 \mathrm{mg} /$ $\mathrm{kg}$ /day escitalopram (Cipralex $20 \mathrm{mg} / \mathrm{ml}$ oral drops; Lundbeck A/S) diluted in normal drinking water to a final concentration of $0.025 \mathrm{mg} / \mathrm{ml}$ in their drinking bottles $(n=10)$. To avoid potential modifying effects of light on drug composition, drinking bottles were composed of a black plastic polymer. Vehicle-treated mice received normal drinking water $(n=10)$. The dosage of escitalopram was calculated to result in around $80 \%$ occupancy of the serotonin transporter (SERT), which is considered therapeutic in humans [28]. Mice were treated for a period of 6 months, during which their daily water intake and intake of escitalopram and body weight were 
calculated on the basis of weekly surveillance. The experiment was terminated when mice reached 9 months of age.

\section{SERT occupancy}

Groups of vehicle $(n=3)$ and 1-month-old escitalopramtreated mice $(n=3)$ were killed by cervical dislocation and investigated by autoradiography. The brains were immediately removed and frozen in isopentane on dry ice $\left(-20{ }^{\circ} \mathrm{C}\right)$. Cryostat sections were cut $20 \mu \mathrm{m}$ thick in the coronal plane using a cryostat (Leica Biosystems, Buffalo Grove, IL, USA) and stored at $-80{ }^{\circ} \mathrm{C}$ for a period of 1 week. Sections were thawed to room temperature (RT), directly incubated for 5 minutes with $1 \mathrm{nM} 3$-amino4-(2-dimethylaminomethylphenylsulfanyl)-benzonitrile $\left(\left[{ }^{3} \mathrm{H}\right] \mathrm{DASB}\right.$; specific activity $\left.80 \mathrm{Ci} / \mathrm{mmol}\right)$, and then dissolved in $50 \mathrm{mM}$ Tris- $\mathrm{HCl}$ buffer containing 150 $\mathrm{mM} \mathrm{NaCl}$ and $5 \mathrm{mM} \mathrm{KCl} \mathrm{(pH} \mathrm{7.4).} \mathrm{Adjacent}$ sections were incubated under identical conditions in the presence of $10 \mu \mathrm{M}$ paroxetine to calculate nonspecific binding. Sections were next washed in icecold $50 \mathrm{mM}$ Tris buffer (twice for 30 seconds each time), dipped in distilled water, dried under a cold stream of air for $2 \mathrm{~h}$ and desiccated overnight $(\mathrm{O} / \mathrm{N})$ in a box containing silica gel. The sections were placed on Kodak BioMax MR autoradiography film (Carestream Health, Skovlunde, Denmark), which was developed and analysed after 25 days.

\section{Stereotactic 5-HTergic lesion induced by DHT}

The 5-HTergic lesion was induced by intracerebroventricular injection of DHT (5,7-dihydroxytryptamine creatinine sulphate salt, catalogue number 37970; Sigma-Aldrich, Brøndby, Denmark). Three-month-old APP/PS1 mice were randomly distributed into groups of sham- and DHT-lesioned mice ( $n=10-13$ /group). Before surgery, $\mathrm{Tg}$ mice were administered $25 \mathrm{mg} / \mathrm{kg}$ desipramine hydrochloride (catalogue number D3900; Sigma-Aldrich) diluted in sterile PBS i.p. to prevent DHT-induced loss of noradrenergic neurons, then they were anaesthetised by an i.p. injection of a mixture of fentanyl citrate $0.315 \mathrm{mg} / \mathrm{ml}$ and fluanisone $10 \mathrm{mg} / \mathrm{ml}$ (Hypnorm ${ }^{\circ}$ V VetaPharma, Leeds, UK) and diazepam 5 $\mathrm{mg} / \mathrm{ml}$ (Stesolid ${ }^{\circ}$ Actavis/Accord Healthcare, Little Island, Ireland) diluted in sterile water. When deeply anaesthetised, mice were placed in a stereotactic frame with an attached microinjection unit (David Kopf Instruments, Tujunga, CA, USA) and injected with 4 $\mu \mathrm{l}$ of a DHT solution $(500 \mathrm{mg}$ DHT/ml physiological saline with $0.1 \%$ ascorbic acid, catalogue number A4544; Sigma-Aldrich,). Sham-operated mice exclusively received the saline composition. DHT and saline were administered at rates of $1 \mu \mathrm{l} /$ minute into the left lateral ventricle using a 10- $\mu$ l syringe (model $801 \mathrm{RN}$; Hamilton, Reno, NV, USA) with the following coordinates: $1 \mathrm{~mm}$ lateral to sagittal suture, $0.5 \mathrm{~mm}$ posterior to bregma and $3.0 \mathrm{~mm}$ below the dura mater. To avoid spillover, syringes were kept in position for 2 minutes after each injection. After surgery, mice received saline and buprenorphine hydrochloride (Temgesic $^{\circ} 1 \mu \mathrm{g} / 20 \mathrm{~g}$ diluted in saline; Reckitt Benckiser Healthcare, Hull, UK). Mice were placed in cages located in heated cabinets $\left(28^{\circ} \mathrm{C}\right)$ for $24 \mathrm{~h}$, after which they were transferred to the animal room and kept until the age of 9 months.

\section{Harvesting of tissue and cerebrospinal fluid}

Mice were anaesthetised with a sublethal dose of pentobarbital (Nembutal $0.15 \mathrm{ml} / 30$ g body weight i.p.; Lundbeck) and positioned for CSF removal under a dissection microscope. The skin of the neck was surgically removed, and the dura covering the cisterna magna was exposed. With a thin, pointy glass capillary tube, the dura was punctured, and 1-5 $\mu \mathrm{l}$ of CSF was extracted from the cisterna magna and placed on dry ice before being stored at $-80{ }^{\circ} \mathrm{C}$ [29]. Next, the brain was removed, and the right hemisphere was isolated for IHC. The neocortex and hippocampus were isolated from the left hemisphere and kept at $-80{ }^{\circ} \mathrm{C}$.

\section{Determination of 5-HT and 5-hydroxyindoleacetic acid}

Levels of 5-HT were determined using highperformance liquid chromatography (HPLC) with electrochemical detection essentially as previously described [30]. Briefly, the neocortex and hippocampus were transferred to ice-cold transmitter buffer $(150 \mathrm{mM}$ $\mathrm{H}_{3} \mathrm{PO}_{4}$ and $150 \mu \mathrm{M}$ pentetic acid) and sonicated in three intervals of 10 seconds each with an amplitude set to 15\% (tissue dilution 1:20 wt/vol). The homogenate was centrifuged at $36,000 \times g$ for 20 minutes at $4{ }^{\circ} \mathrm{C}$, then 40 $\mu \mathrm{l}$ of supernatant was injected into an Agilent 1100 HPLC system (Agilent Technologies, Santa Clara, CA, USA) consisting of an EC 150/4.6 NUCLEODUR 100 3$\mu \mathrm{m}$ C18 gravity reversed-phase column (Machery-Nagel, Düren, Germany). The electrochemical detector (Machery-Nagel) was adjusted to $+0.75 \mathrm{~V}$ against an $\mathrm{Ag} /$ $\mathrm{AgCl}$ reference electrode, and the mobile phase consisted of $16 \%$ methanol and $84 \%$ phosphate buffer (0.1 $\mathrm{M} \mathrm{NaH}_{2} \mathrm{PO}_{4}, 0.65 \mathrm{mM}$ octanesulfonic acid, $0.5 \mathrm{mM}$ triethylamine and $0.1 \mathrm{mM}$ ethylenediaminetetraacetic acid) adjusted to $\mathrm{pH} 3.35$ with $\mathrm{H}_{3} \mathrm{PO}_{4}$. Detection limits for 5-HT and 5-hydroxyindoleacetic acid (5-HIAA) were $20 \mathrm{pg} / \mathrm{mg}$ tissue wet weight.

\section{Tissue processing and IHC}

Isolated hemispheres were fixed in $4 \%$ paraformaldehyde (PFA) in Sørensen's Buffer (SB) for $24 \mathrm{~h}$ followed by $1 \%$ PFA in SB for an additional $24 \mathrm{~h}$, after which they were dehydrated in graded ethanol and xylene and 
embedded in paraffin using an HMP 110 tissue processer (MICROM International, Dreieich, Germany). Paraffinembedded hemispheres were casted into multiblocks and cut into 20- $\mu \mathrm{m}$-thick sections using a Shandon Finesse ME microtome (Thermo Fisher Scientific, Runcorn, UK). Sections were placed on a water-filled paraffin stretch bath (TFB 35; Medite, Burgdorf, Germany) at a temperature of $45^{\circ} \mathrm{C}$, mounted on microscope slides and dried $\mathrm{O} / \mathrm{N}$. Next, sections were incubated for $2 \mathrm{~h}$ at $60{ }^{\circ} \mathrm{C}$ and stored at $4{ }^{\circ} \mathrm{C}$ until use.

Tissue sections were deparaffinised in xylene and rehydrated in graded ethanol before being rinsed in deionised $\mathrm{H}_{2} \mathrm{O}$. Prior to immunostaining for $\mathrm{A} \beta$, sections were de-masked in $70 \%$ formic acid for $30 \mathrm{mi}$ nutes, followed by rinsing in Tris-buffered saline (TBS) with $1 \%$ Triton $\mathrm{X}-100$ (TBS-T) and incubation in TBS with $10 \%$ FBS for 30 minutes to block unspecific binding. Biotinylated monoclonal mouse anti-human $A \beta$ antibody (catalogue number BioLegend, San Diego, CA, USA) diluted 1:500 in TBS with $10 \%$ FBS was then added $\mathrm{O} / \mathrm{N}$ at $4{ }^{\circ} \mathrm{C}$. Sections were washed in TBS-T and immersed in $\mathrm{TBS} / \mathrm{MeOH} / \mathrm{H}_{2} \mathrm{O}_{2}(8: 1: 1)$ for $10 \mathrm{mi}$ nutes, and after an additional rinse in TBS-T, they were incubated with horseradish peroxidase-streptavidin (catalogue number RPN1231; GE Healthcare Life Sciences, Brondby, Denmark) diluted 1:200 in TBS with $10 \%$ FBS at RT for $3 \mathrm{~h}$. Sections were developed by immersion for 5 minutes in TBS with 3,3' -diaminobenzidine $(0.5 \mathrm{mg} / \mathrm{ml})$ and $\mathrm{H}_{2} \mathrm{O}_{2}(0.033 \%)$ added. After a final TBS rinse, sections were dehydrated in a series of ethanol followed by xylene and then coverslipped with PERTEX (HistoLab Products, Askim, Sweden).

\section{Meso Scale Discovery multiplex analysis}

To determine the content of $A \beta 40$ and $A \beta 42$ in the neocortex and hippocampus of escitalopram-treated and DHT-lesioned APP/PS1 mice, samples were sonicated in ice-cold PBS containing protease and PhosSTOP phosphatase inhibitor cocktail (Roche Diagnostics, Mannheim, Germany). The homogenates were spun at $9000 \times g$ for 20 minutes at $4{ }^{\circ} \mathrm{C}$. Supernatants (PBS fraction) were stored at $-80{ }^{\circ} \mathrm{C}$, and pellets were resuspended in an $8 \times$ volume of $5 \mathrm{M}$ guanidine and $50 \mathrm{mM}$ Tris- $\mathrm{HCl}$ buffer. Guanidine and PBS fractions were diluted $2 \times$ for analysis employing the V-PLEX panels for $A \beta 40$ and $A \beta 42$ (A $\beta$ peptide panel 1; Meso Scale Discovery, Rockville, MD, USA) and the sAPP $\alpha$ and sw SAPP $\beta$ kits (Meso Scale Discovery) in accordance with the manufacturer's instructions. Plates were processed in a SECTOR Imager 6000 instrument (Meso Scale Discovery), and data were analysed using Discovery Workbench software (Meso Scale Discovery). Values are presented as picograms of $A \beta$ per milligram of total protein.

\section{Statistics}

Data were analysed with Prism version 6 software (GraphPad Software, La Jolla, CA, USA) and are presented as mean \pm SEM of 10 animals/group for the SSRI study and 10-13 animals/group for the DHT study. Data from the escitalopram-treated and DHT-lesioned groups were analysed by unpaired, two-tailed Mann-Whitney $U$ test. Statistically significant differences are indicated as ${ }^{*} p<0.05,{ }^{* *} p<0.01,{ }^{* * * *} p<0.001$ and ${ }^{* * * * *} p<0.0001$.

\section{Results}

\section{Dosing confirmation studies}

Given that escitalopram is approximately twice as potent as citalopram [31] and that treatment of APP/ PS1 mice with $8 \mathrm{mg} / \mathrm{kg} /$ day citalopram per os was previously reported to reduce A $\beta$ load in APP/PS1 mice [24], we aimed to treat animals with escitalopram at a dose of $5 \mathrm{mg} / \mathrm{kg} /$ day in the drinking water. To achieve this, the daily water intake of adult APP/ PS1 mice was monitored over a period of 4 weeks $(n=5$; data not shown). Thereafter, the occupancy of SERT following 4 weeks of escitalopram treatment at a nominal dosage of $5 \mathrm{mg} / \mathrm{kg} /$ day was determined to confirm dosing effectiveness $(n=3)$ (Fig. 1a, b). The dosage of escitalopram achieved in this study was $3.8 \pm 0.2 \mathrm{mg} / \mathrm{kg} /$ day (Additional file 1: Figure $\mathrm{S} 1 \mathrm{a}-\mathrm{c}$ ). Autoradiography using the SERT-selective radioligand $\left[{ }^{3} \mathrm{H}\right] \mathrm{DASB}$ showed occupancy levels of $79.7 \pm 7.6 \%$ in the neocortex and $66.9 \pm 2.8 \%$ in the hippocampus at this dose of escitalopram (Fig. 1a, b). On the basis of these data, we increased the SSRI concentration in the drinking water to achieve a therapeutically relevant intake of $5 \mathrm{mg} / \mathrm{kg} /$ day.

\section{Daily SSRI intake and effects on body weight}

Three-month-old APP/PS1 mice were treated with 5 $\mathrm{mg} / \mathrm{kg} /$ day escitalopram per os for a period of 6 months, whereas vehicle control-treated mice received normal drinking water ( $n=10 /$ group). Weight development (Fig. 1c), daily water intake (Fig. 1d) and the dosage of escitalopram were monitored throughout the entire experimental period (Fig. 1e). During the experiment, mice weighing $27.7 \pm 1.6 \mathrm{~g}$ (Fig. 1c) drank, on average, 5.20 $\mathrm{ml} /$ day/mouse (Fig. 1d), which corresponded to an intake of escitalopram of $4.79 \pm 0.27 \mathrm{mg} / \mathrm{kg} /$ day (Fig. 1e). At the end of the experiment, the body weight of 9month-old APP/PS1 mice receiving escitalopram was comparable to that of vehicle-treated mice (escitalopram $30.5 \pm 1.3 \mathrm{~g}$, vehicle $31.4 \pm 1.0 \mathrm{~g}$ ) (Fig. 1c)

\section{Escitalopram treatment invokes subtle changes of insoluble amyloid- $\beta$ levels}

CSF was drawn immediately prior to the procurement of the neocortex and hippocampus, and the levels of $A \beta 40$ 

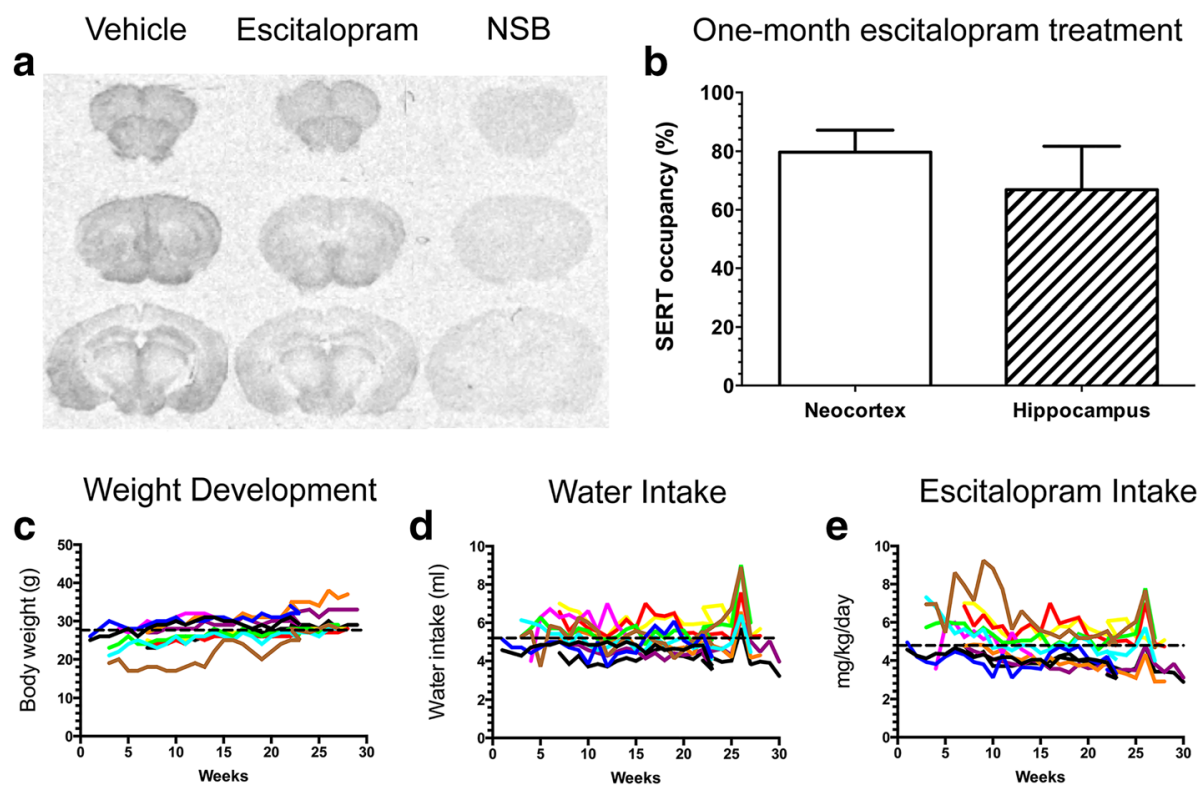

Fig. 1 Escitalopram treatment of APP $P_{S W E} / P S 1_{\triangle E 9}(A P P / P S 1)$ mice. a, b Autoradiograms showing the binding of the 3-amino-4-(2-dimethylaminomethylphenylsulfanyl)-benzonitrile radioligand to brain sections from APP/PS1 mice treated with escitalopram (3.83 $\pm 0.2 \mathrm{mg} / \mathrm{kg} / \mathrm{day}$ ) or vehicle for 1 month, with non-specific binding (NSB) shown to the right (a). Graphic presentation showing the serotonin transporter occupancy (as a percentage) in neocortex and hippocampus (b). c-e Escitalopram intake (c), body weight (d) and water intake (e) in the experimental mice treated with escitalopram from 3 to 9 months of age. The concentration of escitalopram in the drinking water was adjusted to reach $5 \mathrm{mg} / \mathrm{kg} / \mathrm{day}(4.79 \pm 0.27 \mathrm{mg} / \mathrm{kg} / \mathrm{day})$. Each coloured line represents one mouse, and the dashed line is the average for all the mice

and $A \beta 42$ in the CSF were quantified by multiplex analysis. The levels of $A \beta 40$ and $A \beta 42$ were not different between escitalopram-treated and vehicle-treated APP/PS1 mice (Fig. 2a). There was an almost significant reduction in the CSF ratio of $A \beta 42 / A \beta 40$ in escitalopram-treated mice compared with vehicle-treated mice (escitalopram $0.20 \pm 0.02$, vehicle $0.23 \pm 0.01$ ) (Fig. $2 b$ ). Overall, we detected subtle changes only in levels of $A \beta$ species in the CSF of escitalopram-treated mice compared with vehicle-treated mice.

IHC using the $6 \mathrm{E} 10$ antibody showed that plaques of human $A \beta$ were abundant in the neocortex and the hippocampus of both escitalopram-treated and vehicle-treated APP/PS1 mice (Fig. 3a-f). In the neocortex, we observed that levels of $A \beta 40$ in the guanidine fraction increased in escitalopram-treated mice compared with vehicle-treated mice (escitalopram $404 \pm 38 \mathrm{pg} / \mathrm{mg}$, vehicle $262 \pm 43 \mathrm{pg} / \mathrm{mg}, p<0.05$ ) (Fig. $3 \mathrm{~g}$ ). In the PBS fraction, no differences between escitalopram-treated and vehicle-treated mice were observed (Fig. 3i). Levels of A 342 in the cortical guanidine fraction showed a tendency toward an increase in APP/PS1 mice treated with escitalopram compared with vehicle-treated mice (escitalopram $2768 \pm 212 \mathrm{pg} / \mathrm{mg}$, vehicle $2119 \pm 366 \mathrm{pg} / \mathrm{mg}, p=0.089$ ) (Fig. $3 \mathrm{~g}$ ), whereas in the PBS fraction, no differences were observed (Fig. 3i). We did not detect any differences in the ratios of $A \beta 42$ / $A \beta 40$ in the neocortex (data not shown). None of the $A \beta$ species were detected in the neocortex of wild-type mice (Additional file 2: Figure S2). To support the capacity of the Meso Scale Discovery analysis to detect differences in $A \beta$ levels, we also quantified total $A \beta(A \beta 38, A \beta 40$ and $\mathrm{A} \beta 42)$ levels in the neocortex of 6-month-old APP/PS1 mice and compared the level with that of 9-month-old APP/PS1 mice (Additional file 2: Figure S2). There was a significantly higher level of total $A \beta$ in both the guanidine $(p<0.01)$ and PBS $(p<0.001)$ fractions in 9-month-old compared with 6-month-old APP/PS1 mice (Additional file 2: Figure S2). This is in line with results of a former study done at our laboratory showing a progressive $\mathrm{A} \beta$ accumulation with age in the neocortex of APP/ PS1 mice [22].

Levels of A 340 in the guanidine (Fig. 3h) and PBS (Fig. 3j) fractions of the hippocampus were comparable in escitalopram-treated and vehicle-treated mice. The levels of $\mathrm{A} \beta 42$ in the guanidine fraction showed a tendency towards a reduction in mice treated with escitalopram compared with vehicle (escitalopram $55.2 \pm 2.7$ $\mathrm{pg} / \mathrm{mg}$, vehicle $72.8 \pm 12 \mathrm{pg} / \mathrm{mg}, p=0.11$ ) (Fig. 3h).

To further investigate effects of escitalopram treatment on the processing of APP, we quantified levels of sAPP $\alpha$ and sAPP $\beta$, which are the first cleavage products of APP during amyloidogenesis. We observed no differences between vehicle- and escitalopram-treated APP/ PS1 mice in levels of SAPP $\alpha$ in the neocortex (vehicle $0.049 \pm 0.009 \mathrm{pg} / \mathrm{mg}$, SSRI $0.056 \pm 0.008 \mathrm{pg} / \mathrm{mg}$ ) (Fig. 4a) 


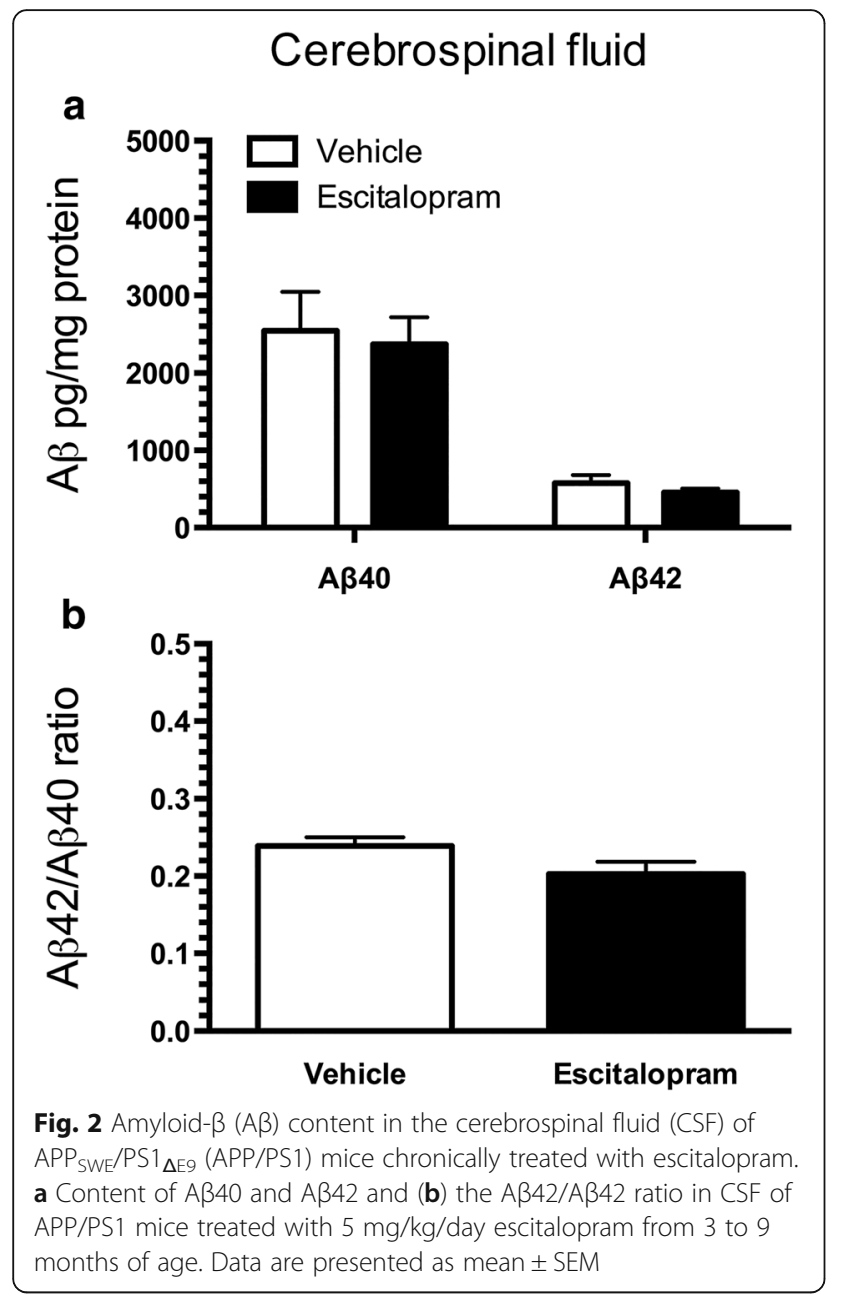

or hippocampus (vehicle $0.029 \pm 0.004 \mathrm{pg} / \mathrm{mg}$, SSRI $0.030 \pm 0.006 \mathrm{pg} / \mathrm{mg}$ ) (Fig. 4b). In addition, levels of $\mathrm{sAPP} \beta$ in the neocortex (Fig. 4c) and hippocampus (Fig. 4d) were roughly eight-fold higher than levels of sAPP $\alpha$ and did not differ between groups.

\section{DHT-induced 5-HTergic deafferentation does not influence amyloid- $\beta$ levels}

Next, we examined if 5-HTergic deafferentation might affect $A \beta$ levels in the brain. Three-month-old APP/ PS1 mice were given intracerebroventricular injections of DHT, which induces degeneration of 5-HTergic neurons in the raphe nuclei [27]. DHT-lesioned and sham-operated APP/PS1 mice were allowed to survive until 9 months of age. DHT-lesioned mice appeared unaffected and showed the same body weight as shamoperated mice.

To evaluate the efficiency of the 5-HTergic deafferentation, tissue samples of neocortex were analysed for the content of 5-HT and its metabolite 5-HIAA (Fig. 5). Levels of 5 -HT were reduced by $64 \%$ in DHT-lesioned mice $(96.73 \pm 10.30 \mathrm{pg} / \mathrm{ml})$ compared with sham- operated mice $(271.00 \pm 28.30 \mathrm{pg} / \mathrm{ml})(p<0.0001)$ (Fig. 5), whereas 5-HIAA decreased by $62 \%$ in DHT-lesioned mice $(52.40 \pm 4.50 \mathrm{pg} / \mathrm{ml})$ compared with sham-operated animals $(137.00 \pm 15.00 \mathrm{pg} / \mathrm{ml})(p<0.0001)$ (Fig. 5).

$\mathrm{A} \beta$-containing plaques manifested in the neocortex and hippocampus of both sham-operated and DHTlesioned mice (Fig. 6a-f). Levels of $A \beta 40$ and $A \beta 42$ in the guanidine and PBS fractions of the neocortex and hippocampus were quantified by multiplex analysis (Fig. $6 g-j$ ). We detected no differences in the levels of $\mathrm{A} \beta 40$ and $\mathrm{A} \beta 42$ in the guanidine and PBS fractions of the neocortex in DHT-lesioned mice compared with sham-operated mice (Fig. 6g, i). Similarly, no differences in the levels of $A \beta 40$ and $A \beta 42$ in the guanidine and PBS fractions of the hippocampus were observed in DHT-lesioned mice compared with sham-operated mice (Fig. 6h, j). No difference in the $A \beta 42 / A \beta 40$ ratio was detected between DHT-lesioned and sham-operated mice (data not shown).

Similarly to the previous study employing escitalopram, we also asked whether APP processing would be affected by 5 -HTergic deafferentation of the cortex, so we measured levels sAPP $\alpha$ and SAPP $\beta$ in the neocortex and hippocampus of sham-operated and DHT-lesioned APP/ PS1 mice (Fig. 7). We noticed that levels of sAPP $\alpha$ in the neocortex of DHT-lesioned mice decreased significantly compared with sham-operated APP/PS1 mice $(p<0.05)$ (Fig. 7a), whereas no changes were detected in the hippocampus (Fig. 7b). Levels of sAPP $\beta$ in the neocortex and hippocampus of sham-operated and DHT-lesioned APP/ PS1 mice did not differ between groups (Fig. 7c, d).

\section{Discussion}

Recently, it was reported that SSRI treatment attenuates plaque pathology in the APP/PS1 mouse model of familial AD [24, 32, 33]. To further test this hypothesis, we treated 3-month-old APP/PS1 mice with the more selective SSRI escitalopram [34] for a period of 6 months at a dosage of $5 \mathrm{mg} / \mathrm{kg} /$ day. This dosage was predicted to inhibit SERT in the therapeutic range, as confirmed by a SERT occupancy assay. We did not observe any changes in body weight, although this is a common side effect of SSRI treatment in both humans and rodents [35-37].

Levels of $A \beta 40$ and $A \beta 42$ were analysed in the CSF, neocortex and hippocampus. In the CSF of APP/PS1 mice, we observed no differences in the levels of $A \beta 40$ and $\mathrm{A} \beta 42$ between escitalopram-treated and vehicletreated APP/PS1 mice. Studies where human CSF has been analysed after orally administered SSRIs are ambiguous and show that although citalopram $(2 \times 30 \mathrm{mg})$ reduces the level of total $A \beta$ in the CSF [32], escitalopram $(2 \times 20 \mathrm{mg})$ has no effect on levels of $\mathrm{A} \beta$ [38]. Analysis of the CSF of 3-month-old APP/PS1 mice that 

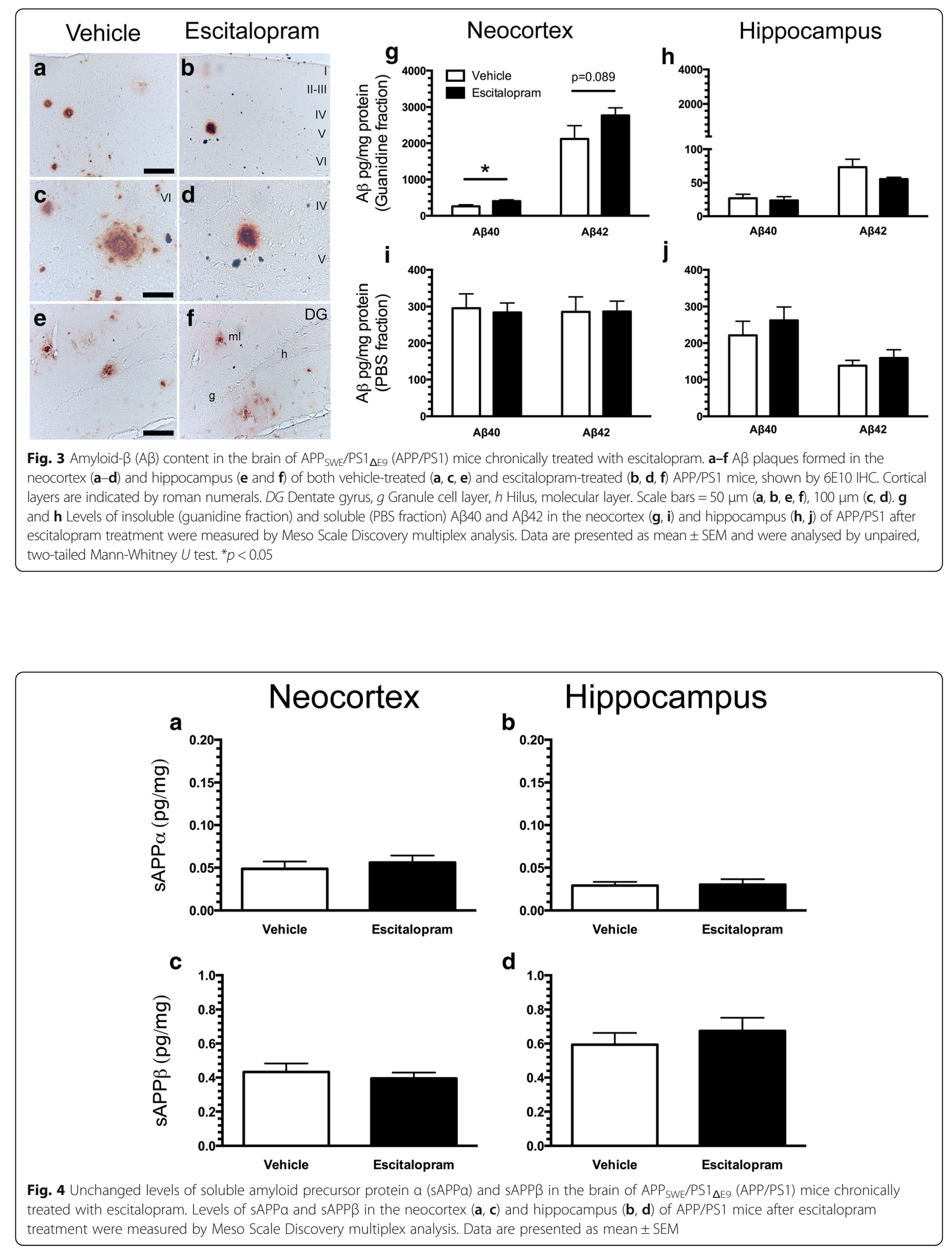


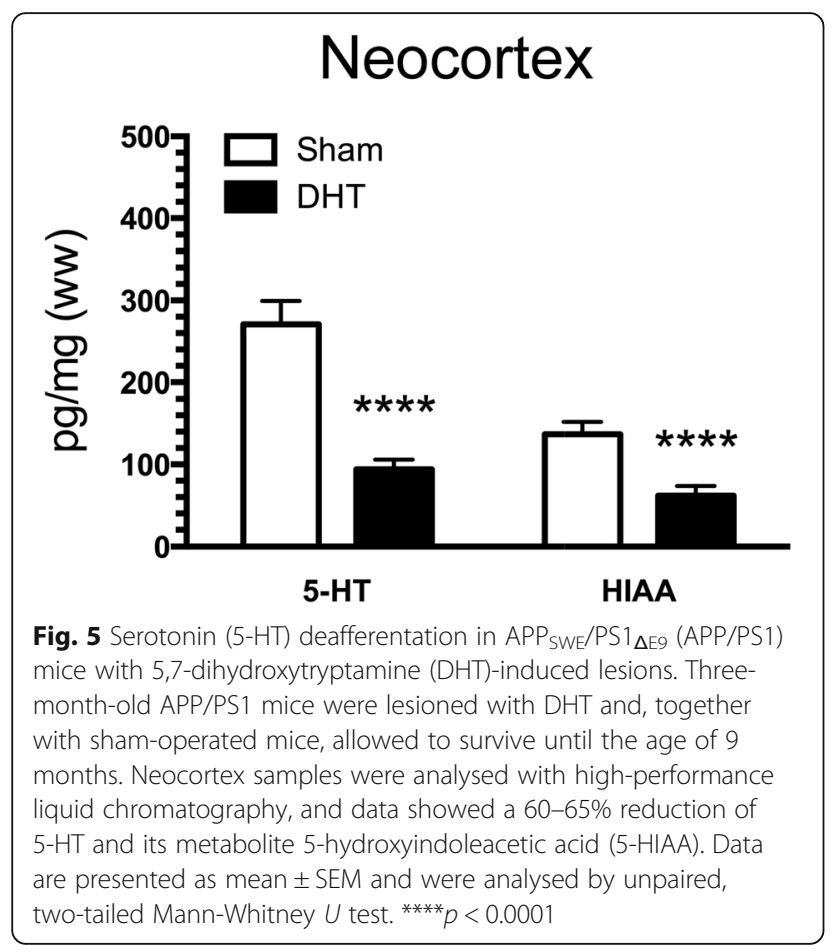

were treated for 4 months with orally administered citalopram (8 $\mathrm{mg} / \mathrm{kg} /$ day $)$ supports citalopram's $A \beta$ reducing potential [24]. Results additionally suggested that citalopram's $A \beta$-reducing effect was likely due to reduced production rather than increased clearance of
$A \beta[24,32]$. The reason for the absence of an SSRI effect in our study is unknown. It is possible that the effect on CSF levels of $A \beta$ of this drug class depends on the type of SSRI used because escitalopram and citalopram, though very similar, show different effects in healthy human subjects. However, as a refinement of the study by Emilsson et al. [38], it was demonstrated that a single i.p. injection of $5 \mathrm{mg} / \mathrm{kg}$ escitalopram in 3- to 4-monthold APP/PS1 mice reduced interstitial levels of $A \beta$ in the hippocampus [39]. Because the interstitial fluid under normal conditions is in equilibrium with the CSF, this observation at least shows that escitalopram can have effects, but it also suggests that some routes of administration may be more suitable than others.

In the neocortex of APP/PS1 mice treated with escitalopram, we observed a tendency toward an increase in the total content of insoluble $A \beta$ compared with vehicletreated mice, which is probably due to an increase in levels of $A \beta 40$ and, to a lesser extent, $A \beta 42$. We observed no changes in the levels of $A \beta 40$ or $A \beta 42$ in the hippocampus of escitalopram-treated compared with vehicle-treated mice. Our observations differ from recent clinical and in vivo studies in which researchers have reported $A \beta$-reducing effects of chronic and acute antidepressant treatment $[24,25,32,33,40]$, although others have also been unable to detect such $A \beta$-reducing effects $[38,41]$. Human subjects with a history of antidepressant drug treatment showed reduced cortical amyloid load compared with non-treated subjects,

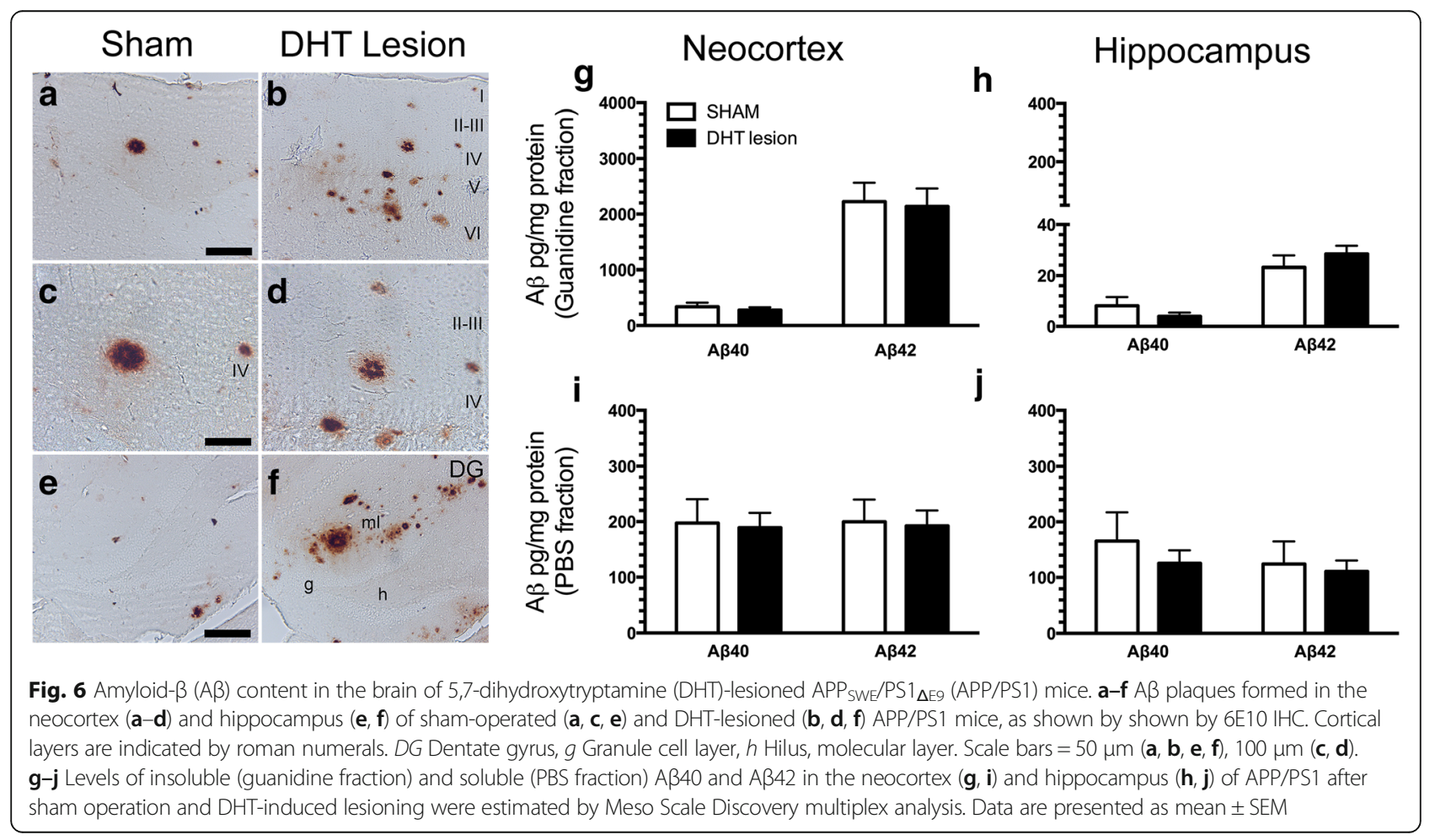




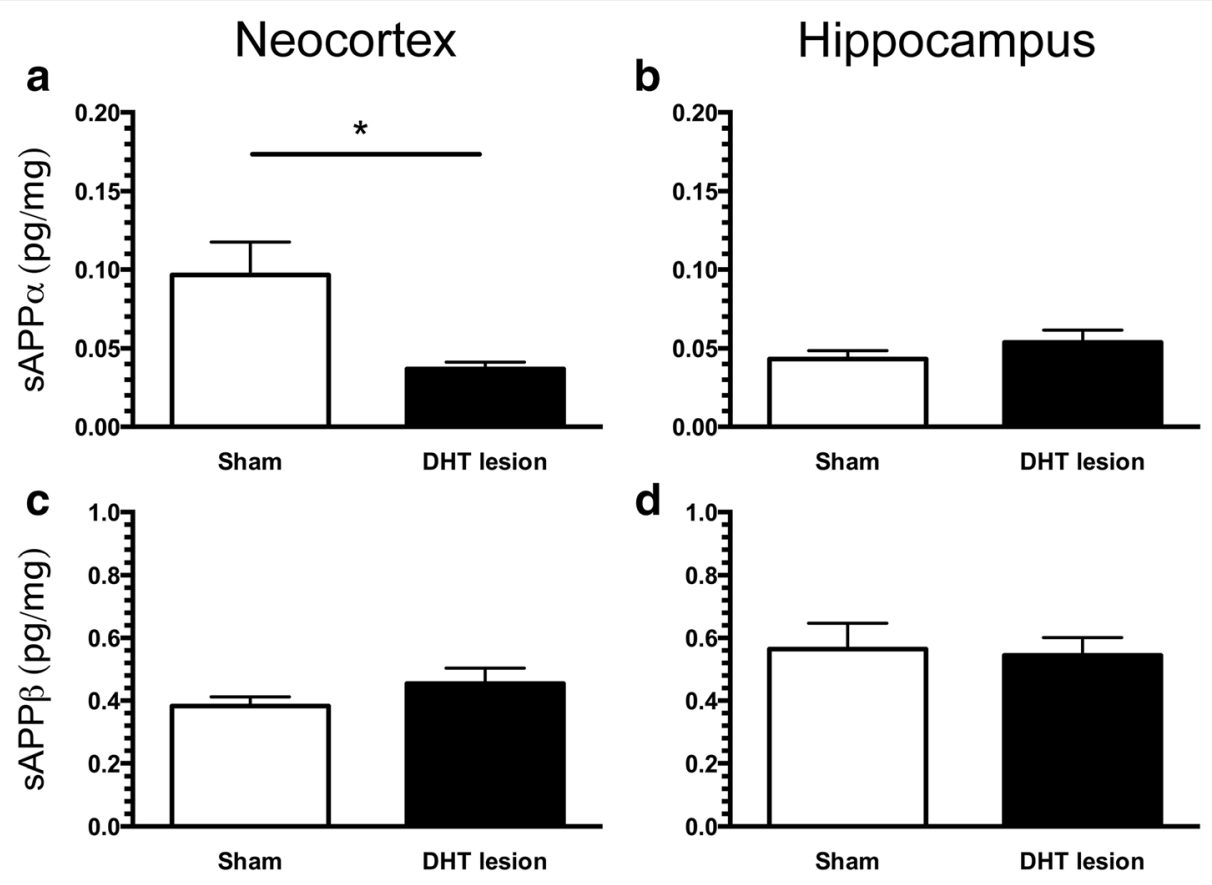

Fig. 7 Levels of soluble amyloid precursor protein a (SAPPa) and SAPP $\beta$ in the brain of 5,7-dihydroxytryptamine (DHT)-lesioned APP SWE $_{\text {IPS1 }} \mathrm{E}_{\mathrm{E}}$ (APP/PS1) mice. Levels of sAPPa and SAPP 3 in the neocortex (a, c) and hippocampus (b, d) of APP/PS1 mice after sham treatment and DHTinduced lesioning were measured by Meso Scale Discovery multiplex analysis. Data are presented as mean \pm SEM and were analysed by unpaired, two-tailed Mann-Whitney $U$ test. ${ }^{*} p<0.05$

estimated by positron emission computed tomographic imaging using the amyloid-binding $\left[{ }^{11} \mathrm{C}\right]$-Pittsburgh compound B (PIB) radioligand [24]. However, as the authors of that paper pointed out, a randomised clinical trial is needed to ascertain whether the observed reduction in PIB binding is indeed caused by SSRI treatment and not by past history of depression or anxiety. It has also been shown that 5 months of treatment with paroxetine i.p. ( $5 \mathrm{mg} / \mathrm{kg} /$ day) reduces $\mathrm{A} \beta 40$ levels in the hippocampus of 10 -month-old $3 \times \mathrm{Tg}$ mice [25], as well as that 4 months of treatment with citalopram ( $8 \mathrm{mg} / \mathrm{kg} /$ day) per os reduces levels of $\mathrm{A} \beta$ and plaque load in the neocortex and hippocampus of 7-monthold APP/PS1 mice [24]. Treatment with citalopram (10 $\mathrm{mg} / \mathrm{kg} /$ day) i.p. for 28 days has furthermore been shown to completely inhibit the growth of plaques without affecting their elimination [32]. Results at our own laboratory have suggested, however, that 9month treatment with paroxetine $(30 \mathrm{mg} / \mathrm{kg} /$ day being reduced to $10 \mathrm{mg} / \mathrm{kg} /$ day and ultimately $5 \mathrm{mg} /$ $\mathrm{kg}$ /day) per os has no effect on plaque load in the neocortex of 18-month-old APP/PS1 mice [41], although a significant effect was observed in the hippocampus of the same mice [40]. Although these findings suggest that a high dosage of paroxetine may have an effect on plaque load at least in the hippocampus, they at the same time emphasise that paroxetine treatment by no means ameliorates plaque load when administered to aging mice in which the amyloid plaques are well-developed.

Escitalopram consists largely of an $S$-enantiomer, whereas citalopram used in the other studies is a racemic mixture of both $S$ - and $R$-enantiomers in the ratio of $1: 1$. Several lines of evidence suggest that the $R$-enantiomer may counteract the effect of the $S$-enantiomer [42], leaving escitalopram more potent than citalopram. In our opinion, it is reasonable to assume that a dose of around $5 \mathrm{mg} / \mathrm{kg} /$ day of escitalopram would at least be equivalent to the effect of $8-10 \mathrm{mg} / \mathrm{kg} /$ day of citalopram, which is around the dose reported to effect amyloidosis in 7-month-old APP/ PS1 mice [24, 32]. It should be noted, however, that Sheline et al. performed an experiment showing that a single i.p. injection of escitalopram $(5 \mathrm{mg} / \mathrm{kg} /$ day) reduced the levels $\mathrm{A} \beta 40$ in the hippocampal interstitial fluid of APP/ PS1 mice [39]. Therefore, it is not possible to completely rule out that escitalopram influences $A \beta$ levels; however, its effect may depend on whether administration is acute or chronic, as well as on the route of administration. It is possible that the $R$-enantiomer present in citalopram may elicit $A \beta$-reducing effects independently of SERT [38], possibly through a direct influence on APP processing $[43,44]$. The $R$-enantiomer has also been found to exert SERT-independent effects by acting on an orphan sigma-1 receptor ( $\sigma 1$, Oprs1), affecting axonal outgrowth and guidance in subpopulations of embryonic thalamocortical neurons $[45,46]$. This being said, a single citalopram 
(10 mg/kg) i.p. injection in APP/PS1 mice was reported to reduce levels of $A \beta 40$ in brain interstitial fluid, possibly through stimulation of $\alpha$-secretase activity involved in the non-amyloidogenic pathway [24]. We therefore also investigated levels of sAPP $\alpha$ and sAPP $\beta$, which are the first products of APP processing when cleaved by $\alpha$ - and $\beta$ secretase, respectively. Because we did not detect any differences in either sAPP $\alpha$ or SAPP $\beta$ protein levels, it is unlikely that the activities of these enzymes were affected by the escitalopram treatment in our study.

The APP/PS1 mice that were lesioned with the neurotoxin DHT were remarkably unaffected by the intervention and showed the same body weight gain as shamoperated mice, similar to what was reported in a previous study of shorter duration [27]. Plaques formed in the neocortex and hippocampus of APP/PS1 mice lesioned with the DHT and in sham-operated mice with similar propensity. Meso Scale Discovery multiplex analysis did not reveal any significant differences in soluble or insoluble fractions of $A \beta 40$ or $A \beta 42$ in the neocortex or hippocampus between DHT-lesioned and sham-operated mice. In a recent study where 7-month-old APP/PS1 mice were examined 2 weeks after DHT lesioning of the raphe, no changes in behaviour or $A \beta$ pathology were detected either. Instead, the authors detected increased tau phosphorylation [27], which is not entirely unexpected, however, because tau phosphorylation increases during neuronal stress $[47,48]$. We also looked into changes in the levels of sAPP $\alpha$ and sAPP $\beta$ to determine whether 5HTergic deafferentation would impact the processing of APP. Interestingly, we found that levels of sAPP $\alpha$ were reduced in the neocortex of DHT-lesioned mice. We are not aware of any studies that have addressed whether $\alpha$ - or $\beta$ secretase is expressed predominantly in fibres or in somata, however, if $\alpha$-secretase is mainly expressed in the 5-HTergic terminals, it would be logical to assume that deafferentation would reduce its presence. Reduction in the levels of the $\alpha$-secretase cleavage product SAPP $\alpha$ were also independent of production of sAPP $\beta$ as well as production of $A \beta$. Overall, deafferentation of cortical 5-HT fibres did not affect levels of $A \beta$ peptides, but it did, however, cause reduced levels of sAPP $\alpha$, the biological significance of which is uncertain.

\section{Conclusions}

Our observations do not support chronic escitalopram treatment as a strategy for anti-A $\beta$ therapy, because we observed significant increases in the levels of insoluble $A \beta$ in the neocortex of APP/PS1 mice. 5-HTergic deafferentation of the cortex did not affect the production of $A \beta$ peptides. However, we did observe a reduction in sAPPa levels. Overall, our findings do not support modulation of the 5-HTergic system with the purpose of reducing $A \beta$ levels in prodromal and early AD.

\section{Additional files}

Additional file 1: Figure S1. Pilot study on the escitalopram treatment experiment. $\mathbf{a}, \mathbf{b}, \mathbf{c}$ In a preliminary escitalopram treatment experiment (a), concentration was closely monitored for a period of 4 weeks, and intake was calculated on the basis of body weight (b) and water intake (c). The average dosage of $3.83 \pm 0.2 \mathrm{mg} / \mathrm{kg} /$ day is represented by the dashed line. (PNG $717 \mathrm{~kb}$ )

Additional file 2: Figure S2. Validation of the mesoscale analysis. Levels of total $A \beta$ were measured in the (a) insoluble (guanidine) and (b) soluble (PBS) fractions in the neocortex of 6-month-old wild-type $(n=2)$, and 6- and 9-month-old APP/PS1 mice $(n=12-18)$. Data are presented as mean \pm SEM and were analysed by unpaired, two-tailed Mann-Whitney $U$ test. ${ }^{* *} p<0.01,{ }^{* *} p<0.001$. (PNG $1888 \mathrm{~kb}$ )

\section{Abbreviations}

AB: Amyloid- $\beta$; AD: Alzheimer's disease; APP: Amyloid precursor protein; APP/PS1: APP SWE $/ \mathrm{PS}_{\triangle \mathrm{E}}$; CSF: Cerebrospinal fluid; [ $\left.{ }^{3} \mathrm{H}\right] \mathrm{DASB}$ : 3-Amino-4(2-dimethylaminomethylphenylsulfanyl)-benzonitrile; DHT: 5,7-

Dihydroxytryptamine; 5-HIAA: 5-Hydroxyindoleacetic acid;

HPLC: High-performance liquid chromatography; 5-HT: Serotonin; 5-HTergic: Serotonergic; O/N: Overnight; PFA: Paraformaldehyde; PIB: $\left[{ }^{11} \mathrm{C}\right]$ Pittsburgh compound B; RT: Room temperature; sAPP: Soluble amyloid precursor protein; SB: Sørensen's Buffer; SERT: Serotonin transporter; SSRI: Selective serotonin reuptake inhibitor; TBS: Tris-buffered saline; TBS-T: Tris-buffered saline with 1\% Triton X-100; $3 \times$ Tg: Triple transgenic

\section{Acknowledgements}

The authors thank Sussanne Petersen for genotyping and mesoscale analysis and Janne Skalshøj, Mohammad Talal Qasem and Alice Lundsgaard Larsen for assistance with histology. Rainer Burger is acknowledged for his assistance with $\mathrm{HPLC}$ measurements.

\section{Funding}

The study was supported by the Danish Council for Independent Research, Fonden til Lægevidenskabens Fremme, The Velux Foundation, A. J. Andersens og Hustrus Fond, Torben og Alice Frimodts Fond and The Lundbeck Foundation, as well as by SDU2020, a fund created by the University of Southern Denmark.

\section{Availability of data and materials}

Supporting data are presented in Additional file 1: Figure S1 and Additional file 2: Figure S2. All datasets used and/or analysed during the present study are available from the corresponding author on reasonable request.

\section{Authors' contributions}

CUVL and BF conceived of the study, analysed data and prepared the first draft of the manuscript. CUVL carried out aspects of the SSRI treatment study. MG assisted CUVL with surgery and contributed to the preparation of the manuscript. AM carried out autoradiography. JW carried out HPLC. JW and $\mathrm{KPL}$ contributed along with $\mathrm{AM}$ to the preparation of the manuscript. CUVL, AM, KPL and BF were responsible for the revision of the manuscript. All authors read and approved the final manuscript.

\section{Ethics approval}

Animal experiments were carried out in accordance with the Danish Animal Inspectorate under the Ministry of Food and Agriculture (2011/562-67 and 2011/561-1950).

\section{Consent for publication}

Not applicable.

Competing interests

The authors declare that they have no competing interests.

\section{Publisher's Note}

Springer Nature remains neutral with regard to jurisdictional claims in published maps and institutional affiliations. 


\section{Author details}

'Department of Neurobiology, Institute of Molecular Medicine, University of Southern Denmark, J.B. Winsløws Vej 25, 5000 Odense C, Denmark. ${ }^{2}$ Molecular Psychiatry, Laboratory of Translational Neuroscience, Department of Psychiatry, Psychosomatics, and Psychotherapy, University of Würzburg, Fuechsleinstrasse 15, 97080 Würzburg, Germany. ${ }^{3}$ Laboratory of Psychiatric Neurobiology, Institute of Molecular Medicine, I.M. Sechenov First Moscow State Medical University, Moscow, Russia.

Received: 26 May 2017 Accepted: 17 August 2017 Published online: 12 September 2017

\section{References}

1. Blennow K, de Leon MJ, Zetterberg H. Alzheimer's disease. Lancet. 2006;368: 387-403.

2. Bartus RT, Dean 3rd RL, Beer B, Lippa AS. The cholinergic hypothesis of geriatric memory dysfunction. Science. 1982;217:408-14.

3. Lyketsos CG, Steinberg M, Tschanz JT, Norton MC, Steffens DC, Breitner JC Mental and behavioral disturbances in dementia: findings from the Cache County Study on Memory in Aging. Am J Psychiatry. 2000;157:708-14.

4. Khaliq S, Haider S, Ahmed SP, Perveen T, Haleem DJ. Relationship of brain tryptophan and serotonin in improving cognitive performance in rats. Pak J Pharm Sci. 2006;19:11-5.

5. Hendricksen $M$, Thomas AJ, Ferrier IN, Ince P, O'Brien JT. Neuropathological study of the dorsal raphe nuclei in late-life depression and Alzheimer's disease with and without depression. Am J Psychiatry. 2004;161:1096-102.

6. Halliday GM, McCann HL, Pamphlett R, Brooks WS, Creasey H, McCusker E, Cotton RG, Broe GA, Harper CG. Brain stem serotonin-synthesizing neurons in Alzheimer's disease: a clinicopathological correlation. Acta Neuropathol. 1992;84: 638-50.

7. Burke WJ, Park DH, Chung HD, Marshall GL, Haring JH, Joh TH. Evidence for decreased transport of tryptophan hydroxylase in Alzheimer's disease. Brain Res. 1990:537:83-7.

8. Francis PT, Palmer AM, Sims NR, Bowen DM, Davison AN, Esiri MM, Neary D, Snowden JS, Wilcock GK. Neurochemical studies of early-onset Alzheimer's disease: possible influence on treatment. N Engl J Med. 1985;313:7-11.

9. Palmer AM, Wilcock GK, Esiri MM, Francis PT, Bowen DM. Monoaminergic innervation of the frontal and temporal lobes in Alzheimer's disease. Brain Res. 1987:401:231-8.

10. Simic G, Stanic G, Mladinov M, Jovanov-Milosevic N, Kostovic I, Hof PR. Does Alzheimer's disease begin in the brainstem? Neuropathol Appl Neurobiol. 2009;35:532-54.

11. Von Linstow CU, Severino M, Metaxas A, Waider J, Babcock AA, Lesch KP, Gramsbergen JB, Finsen B. Effect of aging and Alzheimer's disease-like pathology on brain monoamines in mice. Neurochem Int. 2017;108:238-45.

12. Nyth AL, Gottfries CG, Lyby K, Smedegaard-Andersen L, Gylding-Sabroe J, Kristensen M, Refsum HE, Ofsti E, Eriksson S, Syversen S. A controlled multicenter clinical study of citalopram and placebo in elderly depressed patients with and without concomitant dementia. Acta Psychiatr Scand. 1992:86:138-45.

13. Petracca GM, Chemerinski E, Starkstein SE. A double-blind, placebocontrolled study of fluoxetine in depressed patients with Alzheimer's disease. Int Psychogeriatr. 2001;13:233-40.

14. Lyketsos CG, DelCampo L, Steinberg M, Miles Q, Steele CD, Munro C, Baker AS, Sheppard JM, Frangakis C, Brandt J, Rabins PV. Treating depression in Alzheimer disease: efficacy and safety of sertraline therapy, and the benefits of depression reduction: the DIADS. Arch Gen Psychiatry. 2003;60:737-46.

15. Mowla A, Mosavinasab M, Haghshenas H, Borhani HA. Does serotonin augmentation have any effect on cognition and activities of daily living in Alzheimer's dementia? A double-blind, placebo-controlled clinical trial. J Clin Psychopharmacol. 2007;27:484-7.

16. Jones HE, Joshi A, Shenkin S, Mead GE. The effect of treatment with selective serotonin reuptake inhibitors in comparison to placebo in the progression of dementia: a systematic review and meta-analysis. Age Ageing. 2016:45:448-56.

17. Kessing LV, Sondergard L, Forman JL, Andersen PK. Antidepressants and dementia. J Affect Disord. 2009;117:24-9.

18. Mossello E, Boncinelli M, Caleri V, Cavallini MC, Palermo E, Di Bari M, Tilli S, Sarcone E, Simoni D, Biagini CA, et al. Is antidepressant treatment associated with reduced cognitive decline in Alzheimer's disease? Dement Geriatr Cogn Disord. 2008;25:372-9.
19. Porter RJ, Lunn BS, Walker LL, Gray JM, Ballard CG, O'Brien JT. Cognitive deficit induced by acute tryptophan depletion in patients with Alzheimer's disease. Am J Psychiatry. 2000;157:638-40.

20. Jack Jr CR, Wiste HJ, Lesnick TG, Weigand SD, Knopman DS, Vemuri P, Pankratz VS, Senjem ML, Gunter JL, Mielke MM, et al. Brain $\beta$-amyloid load approaches a plateau. Neurology. 2013;80:890-6.

21. Jankowsky JL, Fadale DJ, Anderson J, Xu GM, Gonzales V, Jenkins NA, Copeland NG, Lee MK, Younkin LH, Wagner SL, et al. Mutant presenilins specifically elevate the levels of the 42 residue $\beta$-amyloid peptide in vivo: evidence for augmentation of a 42-specific $\gamma$ secretase. Hum Mol Genet. 2004;13:159-70.

22. Babcock AA, Ilkjaer $L$, Clausen BH, Villadsen B, Dissing-Olesen $L$, Bendixen AT, Lyck L, Lambertsen KL, Finsen B. Cytokine-producing microglia have an altered $\beta$-amyloid load in aged APP/PS1 Tg mice. Brain Behav Immun. 2015;48:86-101.

23. Liu Y, Yoo MJ, Savonenko A, Stirling W, Price DL, Borchelt DR, Mamounas L, Lyons WE, Blue ME, Lee MK. Amyloid pathology is associated with progressive monoaminergic neurodegeneration in a transgenic mouse model of Alzheimer's disease. J Neurosci. 2008:28:13805-14.

24. Cirrito JR, Disabato BM, Restivo JL, Verges DK, Goebel WD, Sathyan A, Hayreh D, D'Angelo G, Benzinger T, Yoon $H$, et al. Serotonin signaling is associated with lower amyloid- $\beta$ levels and plaques in transgenic mice and humans. Proc Natl Acad Sci U S A. 2011:108:14968-73.

25. Nelson RL, Guo Z, Halagappa VM, Pearson M, Gray AJ, Matsuoka Y, Brown M, Martin B, Iyun T, Maudsley S, et al. Prophylactic treatment with paroxetine ameliorates behavioral deficits and retards the development of amyloid and tau pathologies in 3×TgAD mice. Exp Neurol. 2007;205:166-76.

26. Noristani HN, Verkhratsky A, Rodriguez JJ. High tryptophan diet reduces CA1 intraneuronal $\beta$-amyloid in the triple transgenic mouse model of Alzheimer's disease. Aging Cell. 2012;11:810-22.

27. Ramos-Rodriguez JJ, Molina-Gil S, Rey-Brea R, Berrocoso E, Garcia-Alloza M. Specific serotonergic denervation affects tau pathology and cognition without altering senile plaques deposition in APP/PS1 mice. PLoS One. 2013:8:e79947.

28. Meyer JH, Wilson AA, Ginovart N, Goulding V, Hussey D, Hood K, Houle S. Occupancy of serotonin transporters by paroxetine and citalopram during treatment of depression: a $\left[{ }^{11}\right.$ C]DASB PET imaging study. Am J Psychiatry. 2001:158:1843-9.

29. DeMattos RB, Bales KR, Parsadanian M, O'Dell MA, Foss EM, Paul SM, Holtzman DM. Plaque-associated disruption of CSF and plasma amyloid- $\beta$ (Aß) equilibrium in a mouse model of Alzheimer's disease. J Neurochem. 2002;81:229-36.

30. Gutknecht L, Araragi N, Merker S, Waider J, Sommerlandt FM, Mlinar B, Baccini G, Mayer U, Proft F, Hamon M, et al. Impacts of brain serotonin deficiency following Tph2 inactivation on development and raphe neuron serotonergic specification. PLoS One. 2012;7:e43157.

31. Klein N, Sacher J, Geiss-Granadia T, Mossaheb N, Attarbaschi T, Lanzenberger R, Spindelegger C, Holik A, Asenbaum S, Dudczak R, et al. Higher serotonin transporter occupancy after multiple dose administration of escitalopram compared to citalopram: an [ ${ }^{123}$ I]ADAM SPECT study. Psychopharmacology (Berl). 2007:191:333-9.

32. Sheline $Y$ I, West $T$, Yarasheski $K$, Swarm R, Jasielec MS, Fisher JR, Ficker WD, Yan $\mathrm{P}$, Xiong CJ, Frederiksen $\mathrm{C}$, et al. An antidepressant decreases CSF A $\beta$ production in healthy individuals and in transgenic AD mice. Sci Transl Med. 2014;6:236re4

33. Fisher JR, Wallace CE, Tripoli DL, Sheline YI, Cirrito JR. Redundant $G_{s}$-coupled serotonin receptors regulate amyloid- $\beta$ metabolism in vivo. Mol Neurodegener. 2016;11:45

34. Owens MJ, Knight DL, Nemeroff CB. Second-generation SSRIs: human monoamine transporter binding profile of escitalopram and $R$-fluoxetine. Biol Psychiatry. 2001;50:345-50.

35. Mastronardi C, Paz-Filho GJ, Valdez E, Maestre-Mesa J, Licinio J, Wong ML. Long-term body weight outcomes of antidepressant-environment interactions. Mol Psychiatry. 2011;16:265-72.

36. Raeder MB, Bjelland I, Emil Vollset S, Steen VM. Obesity, dyslipidemia, and diabetes with selective serotonin reuptake inhibitors: the Hordaland Health Study. J Clin Psychiatry. 2006;67:1974-82.

37. Uguz F, Sahingoz M, Gungor B, Aksoy F, Askin R. Weight gain and associated factors in patients using newer antidepressant drugs. Gen Hosp Psychiatry. 2015;37:46-8.

38. Emilsson JF, Andreasson U, Blennow K, Eriksson E, Zetterberg H. Comment on "An antidepressant decreases CSF A $\beta$ production in healthy individuals and in transgenic AD mice". Sci Transl Med. 2014;6:268le265. 
39. Sheline YI, West T, Yarasheski K, Jasielec MS, Hettinger JC, Tripoli DL, Xiong C, Frederiksen C, Grzelak MV, Bateman RJ, et al. Reply to comment on "An antidepressant decreases CSF A production in healthy individuals and in transgenic AD mice". Sci Transl Med. 2014;6:268/r264.

40. Olesen $L \varnothing$, Sivasaravanaparan M, Severino M, Babcock AA, Bouzinova EV, West MJ, Wiborg O, Finsen B. Neuron and neuroblast numbers and cytogenesis in the dentate gyrus of aged $\mathrm{APP}_{\mathrm{Swe}} / \mathrm{PS} 1_{\mathrm{dEg}}$ transgenic mice: effect of long-term treatment with paroxetine. Neurobiol Dis. 2017;104:50-60.

41. Olesen $L \varnothing$, Bouzinova EV, Severino M, Sivasaravanaparan M, Hasselstrom JB, Finsen B, Wiborg O. Behavioural phenotyping of APP ${ }_{\text {swe }} / P S 1_{\delta E 9}$ mice: agerelated changes and effect of long-term paroxetine treatment. PLoS One. 2016;11:e0165144.

42. Mørk A, Kreilgaard M, Sánchez C. The R-enantiomer of citalopram counteracts escitalopram-induced increase in extracellular 5-HT in the frontal cortex of freely moving rats. Neuropharmacology. 2003:45:167-73.

43. Payton S, Cahill CM, Randall JD, Gullans SR, Rogers JT. Drug discovery targeted to the Alzheimer's APP mRNA 5'-untranslated region: the action of paroxetine and dimercaptopropanol. J Mol Neurosci. 2003;20:267-75.

44. Morse LJ, Payton SM, Cuny GD, Rogers JT. FDA-preapproved drugs targeted to the translational regulation and processing of the amyloid precursor protein. J Mol Neurosci. 2004;24:129-36.

45. Bonnin A, Zhang L, Blakely RD, Levitt P. The SSRI citalopram affects fetal thalamic axon responsiveness to netrin-1 in vitro independently of SERT antagonism. Neuropsychopharmacology. 2012;37:1879-84.

46. Lesch KP, Waider J. Serotonin in the modulation of neural plasticity and networks: implications for neurodevelopmental disorders. Neuron. 2012;76: 175-91.

47. Ikeda Y, Ishiguro K, Fujita SC. Ether stress-induced Alzheimer-like tau phosphorylation in the normal mouse brain. FEBS Lett. 2007;581:891-7.

48. Nikkel AL, Martino B, Markosyan S, Brederson JD, Medeiros R, Moeller A Bitner RS. The novel calpain inhibitor A-705253 prevents stress-induced tau hyperphosphorylation in vitro and in vivo. Neuropharmacology. 2012;63: 606-12.

\section{Submit your next manuscript to BioMed Central and we will help you at every step:}

- We accept pre-submission inquiries

- Our selector tool helps you to find the most relevant journal

- We provide round the clock customer support

- Convenient online submission

- Thorough peer review

- Inclusion in PubMed and all major indexing services

- Maximum visibility for your research

Submit your manuscript at www.biomedcentral.com/submit 